DIGITAL COMMONS
@ UNIVERSITY OF SOUTH FLORIDA

Volume 9

Issue 2 Fall 2019

\section{ABO: Interactive Journal for Women in the Arts, 1640-1830}

\title{
The Strength of Weak Ties: Eliza Haywood's Social Network in The Dunciad in Four Books (1743)
}

lleana Baird Dr.

Zayed University, ileana.baird@zu.ac.ae

Follow this and additional works at: https://digitalcommons.usf.edu/abo

Part of the Digital Humanities Commons, Feminist, Gender, and Sexuality Studies Commons, and the Literature in English, British Isles Commons

\section{Recommended Citation}

Baird, lleana Dr. (2019) "The Strength of Weak Ties: Eliza Haywood's Social Network in The Dunciad in Four Books (1743)," ABO: Interactive Journal for Women in the Arts, 1640-1830: Vol.9: Iss.2, Article 4. http://doi.org/10.5038/2157-7129.9.2.1202

Available at: https://digitalcommons.usf.edu/abo/vol9/iss2/4

This Digital Humanities is brought to you for free and open access by Digital Commons @ University of South Florida. It has been accepted for inclusion in ABO: Interactive Journal for Women in the Arts, 1640-1830 by an authorized administrator of Digital Commons @ University of South Florida. For more information, please contact digitalcommons@usf.edu. 


\title{
The Strength of Weak Ties: Eliza Haywood's Social Network in The Dunciad in Four Books (1743)
}

\begin{abstract}
This article uses visualizations of Eliza Haywood's social networks, as described in The Dunciad in Four Books (1743), to make visible her relations with the other characters in the poem, and the nature of these affiliations. The tools used to generate these visualizations are GraphViz, an open source visualization software that creates topological graphs from sets of dyadic relations, and SHIVA Graph, an application used to visualize large sets of networks and navigate through them as through a map. In Eliza Haywood's case, this model of social network analysis sheds new light on the nature of Pope's attack on women writers and on the role Pope assigned to the novelist in the cultural space of early eighteenth-century London. These social graphs also make visible the poem's main "connectors," and its "hall of infamy" (i.e., the seventeen characters that seep into all the networks of the poem). By focusing attention on less dense clusters of relations, this model of social network analysis highlights what Mark Granovetter calls "the strength of weak ties," or the role played by peripheral characters within the poem's plot network.
\end{abstract}

\section{Keywords}

the Dunciad's social networks, Eliza Haywood, Alexander Pope, the strength of weak ties, connectors, bridges, networked public

\section{Creative Commons License}

(c) (1) (9)

This work is licensed under a Creative Commons Attribution-Noncommercial 4.0 License

\section{Cover Page Footnote}

I would like to thank Kathryn R. King and Mark Vareschi for their attentive reading of this article and insightful suggestions for improvement. 


\section{The Strength of Weak Ties: Eliza Haywood's Social Network in The Dunciad in Four Books (1743)}

\section{Introduction}

The Dunciad remains, to date, the poem with the largest number of identifiable characters in British literature: dozens of dunces inhabit its spaces creating, through the mere frequency of the names provided, the strong impression that the individuals referred to are not important as real characters, but as pieces in an intricate mechanism of cultural reassessment. To complicate things even more, many of Alexander Pope's dunces change from one edition to another, are obscure individuals, or are difficult to identify due to the author's elaborate use of sobriquets. Moreover, due to his epic's allusive mood and playful competition between the poem and the apparatus, his dunces' affiliations and the motivations of Pope's attacks are many times unclear. Swift's concern with the Dunciad's indecipherability ${ }^{1}$ echoes, therefore, the problems faced by current readers, who need to approach the text with a key to its social and plot networks to clarify its meanings.

One solution to this dilemma is, of course, punctilious footnoting. Edmund Curll was the first one to annotate the poem in his Key to the Dunciad, published in June 1728. The Scriblerians followed suit, experimenting playfully with ersatz and pedantic footnoting in The Dunciad Variorum (1729). Inspired by the 1716 Geneva edition of Boileau's Works, Pope split his footnotes in Remarks, containing commentaries by Modern critics, and Imitations, containing quotes from Ancient or contemporary authors whose work he admired. In the 1751 edition of Pope's Works, Warburton introduced a third category of notes, Variations, which recorded Pope's successive revisions of The Dunciad. As pointed out by current criticism, Pope's intentions in using the notes were to serve not only satirical but also historical and explanatory functions. ${ }^{2}$ They were meant to ridicule authors and critics who fell short of talent and wit, to set better examples in the Ancients' texts, and to elucidate the context of his war with the dunces. As such, the footnotes do provide the necessary "keys" to contextualize his defamatory assaults, with one major problem: they are utterly unreliable. The mini-narratives they offer are contradictory, incomplete, and obviously biased; they shed only the right amount of light on events to raise questions about his dunces' competence but rarely provide answers to these questions. They involve authorial sympathies or antipathies, heated debates, and scandalous abuse; in short, they function as a lively replica of the disputes occurring in coffeehouses and city streets. The motivations of The Dunciad's attacks on particular characters become, therefore, even more difficult to untangle under the weight of these "clarifications" of Pope's authorial 
intentions. To address this issue, modern editions of the 1729 and 1743 Dunciads contain additional layers of notes to the text and to the Scriblerian footnotes themselves. ${ }^{3}$

I would like to call attention, therefore, to another method of approaching this intricate text that could help in navigating its complicated argument: reading Pope's satire with the tools provided by digital technologies. This method involves, more specifically, the use of digital visualizations to represent some of the social networks described by Pope in his final revision of the poem, The Dunciad in Four Books. Rather than focusing on clarifying information gaps and/or allusions to real life events (as the critical notes to Pope's satirical footnotes do), this approach Xrays the poem by focusing, instead, on character relationships and their dynamics, as they emerge from both text and apparatus (front and back matter, footnotes, headpieces, illustrations). This type of analysis has different goals than untangling the poem's annotative maze: it uncovers more obscure relationships of hostility or alliance, makes evident the main targets of Pope's satire, identifies the protagonists who act as "connectors" in the social network of the poem, draws attention to the role played by peripheral characters within this network, helps elucidate authorial intentions not clearly spelled out by the text or the apparatus, and suggestively illustrates the magnitude of Pope's war with his dunces. As such, this approach can augment discussions about political leanings, gender bias, promotion practices, and canon formation-all issues of paramount importance for the construction of publicness as a moral and political category at the beginning of the eighteenth century.

After a brief description of this digital project, I will focus on the networks of relations that involved Eliza Haywood, one of the founders of the English novel and the victim of the most offensive episode of Pope's satire. The analysis of Haywood's social network will shed new light on her character associations, the motivations for Pope's merciless attack against her, and the role Pope assigned to the novelist in the cultural space of early eighteenth-century London.

\section{Methods and Goals}

As a Social Sciences, Humanities and Performing Arts Network of Technological Initiatives (SHANTI) fellow at the University of Virginia, I had the opportunity of working with Rafael Alvarado, at the time Associate Director of the program, on a project involving the visualization of the fields of relations of six of Pope's dunces: Colley Cibber, the last enthroned King of the Dunces, actor, theater manager, and Poet Laureate to King George II; Edmund Curll, bookseller and publisher who epitomized the unscrupulous rush for publicity of the print market of the time; John 
Dennis, the leading critic of the period and one of Pope's most vituperative attackers; Eliza Haywood, remarkable actress, novelist, playwright, and periodical publisher; John "Orator" Henley, a famous cleric and one of the most controversial public figures in London of Pope's time; and Giles Jacob, legal author with literary ambitions who consistently supported Dennis in his campaign against Pope. ${ }^{4}$ These dunces were selected based on their representative value: they all inhabited key areas of the political, cultural, and religious life of early eighteenth-century London.

I started by capturing all the information relevant to each of these characters in a spreadsheet indicating the dunce's name, his or her location within text (i.e., apparatus or poem, with book and line numbers), the passage in which the assertion takes place (e.g., "See in the circle next, Eliza plac'd..."), person he/she is linked to, the nature of this affiliation (similarity, dissimilarity, character attacked, or character defended), alternative names or references used by the poet to identify the character (i.e., Haywood is also called "Juno," or "Pholoe"), and a brief description of the character's role within the poem (Figure 1). When the protagonist is mentioned in the main text, the exact quote was recorded in red to account for the number of instances he/she appears in the poem vs. the apparatus (e.g., in Haywood's case, the ratio is $3: 15$ ). By using a simple script (Perl), we then converted this table into a series of graph data structures that could be interpreted by a graph visualizer.

Next, we generated images of the social networks in which these characters are involved by using two tools: GraphViz and Shiva Graph. GraphViz is an open source visualization software that creates topological graphs from sets of dyadic relations. Each graph represents a view of the social network data expressed directly and indirectly in Pope's Dunciad, as a neato, circo, or dot algorithm. ${ }^{5}$ In the GraphViz visualizations, the relationships among characters were color-coded: green edges indicate similarity (i.e., Eliza Haywood is similar to Edward Ward as both are described as dunces supporting Curll's campaign against Pope), dotted red edges indicate dissimilarity (i.e., Curll is described as a less skilled editor than Lewis Theobald), red edges indicate character attacked (i.e., Pope was attacked by Colley Ciber), and dotted green edges indicate character defended (i.e., John Dennis was defended by Giles Jacob during his campaign against Pope). Shiva stands for SHANTI Interactive Visualization Application. This application can be used to create charts, graphs, tables, maps, and other data representations that help visualize large sets of networks and navigate through them as through a map. The Shiva graph shows character relationships as well (green/similarity, orange/dissimilarity, $\mathrm{red} /$ character attacked, blue/character defended, and gray/other or unknown relationship), but it is interactive, indicating, for instance, the number of connections of a particular character when clicking on his or her name. 
We have created, thus, social graphs that make visible what Alex Woloch describes as the "space of the protagonist": 6 one's network of relations with the other characters in the poem, and the nature of these affiliations. Although it is important to recognize that, just like maps of large geographical areas, some of these graphs are difficult to read on a computer screen due to the amount of data they represent, they can provide invaluable insights into the argument of the text. As demonstrated below, this model of social network analysis brings to light data that is structurally embedded in the poem but not obvious or immediately legible given the amount and complexity of information. Our initial goals were: a) to clarify the relationships of these particular dunces and/or Pope and his friends, allies, or defenders; b) to make visible networks of relations that could bring to surface, in Franco Moretti's words, "hidden patterns"7 of contacts and exchange, and c) to assess the magnitude and the social ramifications of Pope's attacks. Our final results led, excitingly, to much more than that.

\section{The poem's plot network: Alexander Pope's Duncification of Eliza Haywood}

Before launching into a more granular analysis of Eliza Haywood's social network, I will give a quick overview of the nature of her relationship with Pope to provide context to this discussion. The plot network of The Dunciad in Four Books, that is, the story told by the relationships in which a character is involved, rather than the story told by the poem itself, insistently associates her status as a novelist (Haywood was notoriously known after 1730 as Mrs. Novel ${ }^{8}$ ) with moral promiscuity. The first reference to Haywood belongs to Martinus Scriblerus, who, in the prefatory material, singles her out as a "libelous Novellist" ("Martinus Scriblerus of the Poem"). Haywood is then mentioned in the second episode of The Dunciad's epic games, the pissing contest, where the loser is offered as compensation prize a "China Jordan" and the victor wins the works and person of Eliza Haywood. The contest engages in the 1743 edition of the poem the publishers and booksellers Edmund Curll and Thomas Osborne, both well-known for their shameless marketing practices: ${ }^{9}$

See in the circle next, Eliza placed,

Two babes of love close clinging to her waist;

Fair as before her works she stands confess'd,

In flowers and pearls by bounteous Kirkall dress'd.

The goddess then: 'Who best can send on high

The salient spout, far-streaming to the sky;

His be yon Juno of majestic size,

With cow-like udders, and with ox-like eyes.

This China Jordan let the chief o'ercome 
Replenish, not ingloriously, at home.'

(The Dunciad in Four Books, II, 1. 157-166)

As its name indicates, the pissing contest is an irresolvable argument, a dispute in which the two parties challenge each other, are both injured in the process, and ultimately nobody loses or wins. It is also a game whose origin indicates a territorial claim (the "pissing grounds" were urinated on as a mark of ownership), and as such it underscores the two publishers' mindless engagement in the market dynamics, to the extent that they consent to public exhibitionism. The location of the pissing contest on the London streets turns them into an immense urinal, an association which highlights in a memorable way the gross realities of an urban environment, but also metonymically identifies the two male protagonists, Curll and Osborne, with the dirt contained by such urinal. The lack of hygiene of a crowded city is equated, through a process of reification that associates a human subject with a material trophy, with lack of literary value: as a dunce, Eliza Haywood is herself a sort of debris that insidiously pollutes the ecosystem of the city. Pope's moral indictment associates, thus, bad writers with bad persons, the lack of talent with moral corruption, and highlights in the metaphor of the city sewer their virus-like capacity to contaminate the urban body. ${ }^{10}$

In the very first footnote to this episode, Eliza Haywood is introduced as a representative figure for a whole category of "scriblers":

In this game is exposed, in the most contemptuous manner, the profligate licentiousness of those shameless scriblers (for the most part of that Sex, which ought least to be capable of such malice or impudence) who in libelous Memoirs and Novels, reveal the faults or misfortunes of both sexes, to the ruin of public fame, or disturbance of private happiness. Our good poet (by the whole cast of his work being obliged not to take off the Irony) where he could not shew his indignation, hath shewn his contempt, as much as possible; having here drawn as vile a picture as could be represented in the colours of Epic poesy. (II, note to 1. 157)

The note is remarkable for its obvious gender prejudice: the "shameless scriblers" alluded to here belong, most of them, to the female sex, and are all authors of "libelous Memoirs and Novels," who trespass not only the public decorum but also the clearly delineated boundaries of the private sphere. Seemingly, what Pope understands by novel in The Dunciads refers mainly to encrypted romans-à-clef, offensive "memoirs" that attacked private or public individuals under the guise of fictional sobriquets. Such "novels" were actually nothing but scandal chronicles 
teeming with contemporary gossip, or highly eroticized prose ${ }^{11}$ where the victims' "private happiness" was shattered by the "profligate licentiousness," "malice," and "impudence" of the authors, and their "public fame" was irremediably compromised by the "vile" gossip recorded in print and circulated as truth. The gender partisanship is coupled here with a genre bias which opposes "the good poet" to "the libelous" novelists, the "Epic poesy" to the "licentiousness" of the "Memoirs," and, more broadly, the high culture epitomized by Pope to the popular productions that fueled the emerging entertainment industry of the time.

A further footnote to the same line explicates Pope's qualification: Haywood is an "authoress of those most scandalous books called the Court of Carimania and the New Utopia," as well as of the History of Clarina, a short text printed by Curll in The Female Dunciad (1728). According to some critics, ${ }^{12}$ The Memoirs of a Certain Island Adjacent to the Kingdom of Utopia (1724) contained a veiled attack against Pope's friend, Martha Blount, who, under the name of Marthalia, was described as "the most dissolute and shameless of her sex." 13 This identification is contested by Kathryn R. King, who reads Haywood's attack in the context of the financial collapse of the South Sea Company, identifying this character with Sir John Blunt, one of the company's directors, whom Pope admired. ${ }^{14}$ The Memoirs also attacked Martha Sansom (née Fowke) in the character of Gloatitia, who is described as a lecherous woman and a bad poet. ${ }^{15}$ These bouts provoked both Savage's and Pope's outraged reactions and the immediate disapproval of the Hillarian circle to which both Sansom and Haywood belonged. Although in one of the stories included in the Memoirs Haywood tried to win back an estranged Savage by writing an idealized story of his birth ("History of Masonia, Marville, and Count Riverius"), ${ }^{16}$ Haywood's personal bouts weighed more for Savage and Pope, who hit back vigorously in The Authors of the Town (1725), An Author to Be Lett (1729), and the 1728 and 1729 Dunciads. Likewise, The Secret History of the Present Intrigues of the Court of Caramania (1727), another political allegory, whose central characters represent the king of England, his queen, and his mistress, libeled Pope's friend, Henrietta Howard, in the character of Isamonde, mistress to the married prince Theodore (aka George, Prince of Wales), as well as several other individuals close to Pope. ${ }^{17}$ After this attack, the Scriblerians' animosity reached its peak, Swift calling Haywood a "stupid, infamous, scribbling woman" in his October 1731 letter to Henrietta. ${ }^{18}$ The Court of Caramania was also singled out on the cover of The Dunciad Variorum (1729), together with "Haywood's Novels," which is a clear indication of Pope's ire. Finally, Irish Artifice; or, the History of Clarina, the last title mentioned in the note, was an innocuous piece that had nothing to do with Pope, except for being included in Curll's infamous volume of anti-Pope pamphlets, The Female Dunciad. ${ }^{19}$ In his note, however, Pope used a quote from 
Clarina which, taken out of context, sounded like a confession of Haywood's shortcomings.

Another note to line 160 refers to Haywood's portrait drawn by Elisha Kirkall (actually George Vertue), which was included in the first of her four volumes of works, Secret Histories, Novels and Poems (1725). Pope seemed to have been familiar with this edition, which contained some of Haywood's most popular novels (Love in Excess, The British Recluse, Idalia, Fantomina, The Masqueraders), as well as a short piece in verse dedicated to Hillarius, a nickname bestowed on Aaron Hill, another one of Pope's dunces, by Haywood herself. ${ }^{20}$ Hill was not the only "dunce" Haywood cultivated: she also had connections with William Bond ${ }^{21}$ and was in friendly terms with Lewis Theobald, from whom she had received a copy of The Dunciad Variorum with dedication. Finally, Appendix II to The Dunciad, ${ }^{22}$ which contains the notorious "List of Books, Papers, and Verses" that abused Pope, mentions another lampoon against the poet, Memoirs of the Court of Lilliput (1727), incorrectly attributed by Pope to Haywood. ${ }^{23}$ The Memoirs contained the following passage that hit at the very core of Pope's sensibilities:

And besides, the inequality of our Stature rightly consider'd, ought to be for us as full a Security from Slander, as that between Mr. P_pe, and those great ladies who do nothing without him; admit him to their Closets, their Bed-sides, consult him in the choice of their Servants, their Garments, and make no scruple of putting them on or off before him: Every body knows they are Women of strict Virtue, and he a harmless Creature, who has neither the Will, nor Power of doing any farther Mischief than with his Pen, and that he seldom draws, but in defense of their Beauty; or to second their Revenge against some presuming Prude, who boasts a Superiority of Charms: or in privately transcribing and passing for his own, the elaborate Studies of some more learned Genius. ${ }^{24}$

The remarks about Pope's defense of the women he admired and his passing for his own "the elaborate Studies of some more learned Genius" seem to point to his relationship with Lady Mary Wortley Montagu, whom he, indeed, praised in his verses, and whose Town Eclogues had been published by Curll under Pope's and Gay's names in 1716. That "Captain Gulliver" was not Eliza Haywood had, however, little relevance, as Pope was convinced of her authorship and, consequently, turned the novelist into the prize of the most offensive episode of his mock epic, the booksellers' pissing contest. 
The effects of Pope's attack on Haywood in The Dunciad are subject to debate. While some critics maintain that they hurt Haywood's career, leading to a decadelong decline in her publication rate, ${ }^{25}$ more recent criticism asserts that such assessments are misleading: rather, Haywood made a deliberate choice to dedicate herself to the theater in the 1730s, being active as an actress and a writer for and about the stage. ${ }^{26}$ Regardless of these assessments, it is beyond doubt that Haywood's public presence as an actress, novelist, political commentator, and member of literary coteries in the $1720 \mathrm{~s}$, her involvement in theater and political criticism in the 1730s, and her novelistic output and engagement with the Addisonian periodical in the 1740 s are significant. ${ }^{27}$ Therefore, as this analysis tries to suggest, the attacks against Haywood in The Dunciad may have been motivated less by personal animosities and more by an anxiety about the emergence of the woman writer on the literary marketplace and her promotion of a particular type of product. As Anthony Pollock compellingly argues, during the first half of the Eighteenth century the discourse against female publicness was gender-biased and the "desire for authoritative reputation through the broadcasting of scandal was a particularly masculine, public-sphere phenomenon, carried out by 'male-gossips"" in the first place. ${ }^{28}$ The theme of women's damaging trespassing from private to public spaces, which becomes a leitmotif of Pope's treatment of his female characters throughout the poem, may be, thus, explained by cultural changes taking place at the time.

Haywood's only reference to Pope's attack is a passing remark made in the Preface to Frederick, Duke of Brunswick-Lunenburgh (1729), where she deems herself "beneath the Censure of the Gyant-Criticks of this Age."29 Although Pope's, Savage's, and Swift's attacks (to mention just a few) did affect her personal and authorial reputation during her lifetime, she had her defenders later on, the most important being Clara Reeve, who praised her efforts for moral rehabilitation in The Progress of Romance (1785). In recent years, the reassessment of her career has emphasized her constant presence in all areas of public discourse, be they political, cultural, or, more broadly, of moral concern. ${ }^{30}$ Moreover, although the plot network disclosed by Pope's satire attaches Haywood to Curll and his circle, insistently associating her with the print trade practice capitalizing on gossip and scandal, it also singles her out as the most significant female author on the literary marketplace. The irony of the situation is that, in her case, Pope's instinct for cultural prominence was flawlessly precise: Haywood was, indeed, the most remarkable feminine voice in the emerging public sphere of the time. 


\section{Eliza Haywood's Social Network}

In her article, "Cut the Caterwauling: Women Writers (Not) in Pope's Dunciads," Valerie Rumbold points out that "only five women writers are consistently and identifiably attacked in every one of the Dunciads"31: Margaret Cavendish, Duchess of Newcastle (ridiculed for her literary over-productivity), Elizabeth Thomas (Curll's "Corinna," attacked for her unauthorized sale to Curll of Pope's letters to Cromwell), Susannah Centlivre (contemptuously depicted as a cook's wife due to her hit at Pope's translation of the Iliad in "The Catholic Poet"), Lady Mary Wortley Montagu (accused of lewdness and unfair attacks against Pope), and Eliza Haywood (for her attacks against his friends, Martha Blount and Henrietta Howard). Two other targets of Pope's satire would have been, according to Rumbold, Mary Pix, prolific playwright and author of occasional poems, and "N_ n," identified by Maynard Mack as Lady Frances Norton, an author of poems of religious inspiration. The latter authors were the main protagonists of a caterwauling episode which Pope had planned to include in the noise-making competition in an earlier version of the poem. The motivations of these attacks are not always obvious. As Rumbold explains, "attacks on women writers [in the Dunciads] are neither particularly numerous nor unambiguously focused on a notion of female publication as intrinsically offensive." 32 Rather, in the critic's opinion, with the exception of Duchess of Newcastle, all of these authors "wounded him in sensitive areas which bore centrally on his self-image and emotional commitments," 33 so Pope's attacks may have been triggered by personal reasons, rather than by a focused agenda against women writers. Although Rumbold admits that the eliminated caterwauling episode may indicate Pope's intent to launch a broader attack against women writers at large, this assumption still needs additional support. An analysis of Haywood's social network may eventually provide one.

Although these five characters seem, at first glance, to form the poem's social network of women writers, at a closer analysis none of these characters are connected with each other in the poem itself. As shown in Figures 2 and 3, Eliza Haywood is directly connected with only one female author, Anne Tanneguy-Le Fèvre Dacier, a character not even mentioned in Rumbold's analysis. Indeed, Madame Dacier appears only fleetingly in a footnote to the pissing contest episode (note to 1. 165). The pairing of Haywood and Dacier revealed by these visualizations is hugely incongruous as one's distinguished scholarship does not equal by any means the other's work as a "scribbler," so the motivations of this intriguing association give me pause. The note reads as follows:

In the games of Homer, Il. xxiii, there are set together, as prizes, a Lady and a Kettle, as in this place Mrs. Haywood and a Jordan. But 
there the preference in value is given to the Kettle, at which Mad. Dacier is justly displeased. Mrs. H. is here treated with distinction and acknowledged to be the more valuable of the two. (note to 1 . 165)

A possible reason for attacking Dacier may be her biting defense of Homer against Pope's interpretation of his work in his Preface to the Iliad. Dacier was a renowned French philologist whose magnum opus was the translation from Greek into French of the Iliad (1711) and the Odyssey (1716). Pope consulted these translations when he undertook his own translations of the Iliad (1715-1720) and the Odyssey (1725), and he acknowledged his use of Dacier's notes in writing his own commentaries to the Homeric poem. However, in Dacier's second edition of her translation of the Iliad (1719), she included some damaging "Reflexions sur la premiere Partie de la Preface de M. Pope," based on the imperfect translation of Pope's preface to his own translation of the Iliad by André-Robert Perelle. These observations were published by Curll first individually, as "Madam Dacier's Reflections upon Mr. Pope's Account of Homer, in his Preface to the Iliad" (1724), and then in The Popiad (1728), together with other offensive pieces by Dennis and Lady Mary Wortley Montagu. Dacier's attack against the poet was particularly offensive: she accused Pope of presenting Homer as "a confused Heap of Beauties, without Order or Symmetry," 34 corrected "two considerable Errors" 35 Pope made in his commentary (i.e., regarding the origins of the fable and his misinterpretation of Aristotle's words), and concluded her reflections in a sardonic way, by ridiculing the translator:

So bright a Man will not confine himself to perfect only the Art of Epick Poetry, that would be a trifling Matter: No; he will perfect the Art of Politicks, much more valuable and more important than that of Epick Poesy. A Man capable to correct Homer will be able to form the Manners of Men... ${ }^{36}$

These conclusions were doubled in The Popiad by those of the publisher, Edmund Curll, who added fuel to the fire:

The most partial Popeling, or Dunciader, cannot but allow, upon an impartial Perusal of what Mr. Dennis and Madam Dacier have herein advanced, that, the present Residence of the Goddess of Dulness is at Twickenham. ${ }^{37}$

This criticism caused the obvious discomfort of Pope, who complained that "Madam Dacier has not done me the honour I expected as a Critick." 38 However, 
despite the harshness of Dacier's critique, it is well known that Pope respected her as a scholar. Moreover, the note to line 165 does not seem to suggest that Pope wrote out of a sense of personal grievance; rather, he seems concerned with the impact of female authorship more generally. In his note, Pope explains that he tried to please Dacier by answering her critique of the choice of gifts offered in the wrestling event in the Illiad (Book XXIII): because she decried the preference in value given to the "Kettle" over the "Lady," in the Dunciad he heightened the value placed on Haywood above that of the China jordan. Pope's note, however, implies the critic's microscopia: caught up in details over which prize is "more valuable," Dacier ignores the more important issue of the "Lady"s" gender, of a woman slave being offered as a consolation prize to a male competitor. This issue is overlooked by "Mad. Dacier" (the abbreviation is also telling!) as long as her value hierarchies are in place. By substituting the slave in the Homeric poem with a woman writer in his own poem and offering her as the main prize instead of the China jordan, Pope calls attention to the unintended consequences of such a revision. Thus, "pleasing" Dacier in his poem (significantly, Pope also refers to Haywood as "the pleas'd dame") involves a process of objectification of a female author, which turns her into a recipient of the fluids of the male body (Eliza and the chamber pot are both prizes in the pissing contest). The pairing of the two female authors is, therefore, deeply subversive, as it implies, in Haywood's case, a "madness" of the imagination and, in Dacier's case, the "madness" of the industrious pedant. This association is also placed in a gendered context, which helps clarify the motivations of Pope's attack on women writers. Male hierarchies function here in a deflating way, creating damaging fictions about women's improper behavior and associating the contributions of two voices of authority in the women's literary community with lack of reason. ${ }^{39}$ More importantly, this association betrays Pope's hidden acknowledgment of their significant cultural impact on the literary marketplace and, implicitly, his anxiety about the emergence of the woman intellectual as an important agent of modernity.

Another interesting finding is Haywood's strong connection with Edmund Curll, ${ }^{40}$ as shown by the undirected graphs in Figures 2 and 3. Indeed, although the competitors in the pissing contest change from one edition of the poem to another, the victor, Edmund Curll, stays the same. As described by these graphs, the connection between the two forms a strong tie: it is bidirectional (the two characters interact with and support each other), and it occurs more than once. This connection, however, is not immediately obvious when analyzing their relationship outside the poem: Curll and Haywood did not collaborate before the attacks in The Dunciad, despite Haywood's prolific activity as an author. Her involvement with Curll was limited to contributing a piece to The Female Dunciad, which was published after the two were associated in the poem. The connection suggested by 
the poem is, therefore, not that of a publisher promoting an author. An additional note to 1.157 clarifies the nature of their relationship, albeit in an indirect way: through her character, Urania, Haywood praised the editor of The Rover (identified by Pope as Curll) for his "undertakings for Reformation of manners," while Curll accused Haywood of promiscuity in the Key to the Dunciad (1728), where he explicates the reference to "the two babes of love" as "the Offspring of a Poet and a Bookseller." In other words, the two are connected over issues that involve (im)moral behavior: while Haywood (through Urania) praises "the sweetness of his disposition and a tenderness with which he considered the errors of his fellow creatures.... and the inadvertencies of her own life," Curll besmears Haywood in real life and wins her in the poem in a contest that bears obvious sexual connotations.

A less obvious connection between the two is also created by the cover illustration to The Dunciad Variorum, where Haywood's novels appear in the pile of publications carried by the book-laden ass, together with works by Leonard Welsted, Edward Ward, John Dennis, Lewis Theobald, and John Oldmixon (Figure 8). The graph in Figure 4 clarifies, again, relationships of partnership otherwise obscure: all these authors had connections with Curll, who had published or sold their works, and they fueled in one way or another his campaign against Pope. ${ }^{41}$ From this perspective, David Vander Meulen's identification of the owl on the cover of the 1728 Dunciad with Edmund Curll, who had published a piece titled Laus Ululae. The Praise of Owls in $1726,{ }^{42}$ can be extended here: the bookseller seems to preside over a society of authors whose common denominator is their appetite for scandal and improper public behavior. ${ }^{43}$

The group of authors singled out on the cover of The Dunciad Variorum have in common, however, more than their support for Curll's campaign against Pope. Leonard Welsted (1688-1747) was a poet, playwright, and translator who relied heavily on influential patrons; his quarrel with Pope started in 1717, when he published "Pælemon to Cæliat at Bath; or The Triumvirate," a satire on Three Hours after Marriage authored by Gay, Arbuthnot, and Pope. Edward Ward (16671731) was a poet and prose writer famous for his monthly periodical The London Spy (1698-1700). He only attacked Pope after his inclusion in The Dunciad, where he was described as an author writing for an uneducated public. John Dennis (16581734) was the leading critic of Pope's time and one of the most vituperative attackers of his work following an (unprovoked) attack by Pope in Essay on Criticism (1711). Lewis Theobald was a textual editor and playwright who aroused Pope's ire because of his publication of Shakespeare Restored (1726), a book in which he corrected many of Pope's errors in Shakespeare's Works (1723-1725), seriously shattering the poet's reputation as a textual editor. ${ }^{44}$ Finally, John 
Oldmixon (1673-1742) was a historian, playwright, and pamphleteer who ended up in The Dunciad because of his political attacks on Swift, ${ }^{45}$ Pope's closest friend, and his intense support of the Whig party in the Flying Post and other progovernmental publications. ${ }^{46}$ As seen from this brief account, the issues bringing together these characters are multifarious: they are political (each of them, with the notable exception of Haywood, were Whig supporters), moral (each of them benefitted from the patronage practice widespread at the time), and cultural (each of them wrote pieces that, in Pope's view, would not stand the test of time, and had been supported by Dennis's criticism). In other words, the social network highlighted by these graphs suggests not only camp affiliations, (their common support of Curll in his campaign against Pope) but also the main directions of Pope's attack against his dunces.

Haywood's network is less dense when compared to that of Curll, Dennis, or Cibber and, unlike them, she is involved exclusively in relationships of similarity (as a dunce attacking Pope) or antagonism (as a victim of Savage's attack). Moreover, most of her connections with members of her network are directed, that is they do not involve connections among these members within her network. This is made obvious by Figure 7, which shows that Haywood is the only one connected with Dacier, Kirkall/Vertue, and Savage, characters who are peripheral to the larger social network of the poem; however, the importance of these "weak ties"47 (and of Haywood's thinner social network as a whole) should not be underestimated: the connections with people who are not members of one's close group of friends are important because they provide a bridge, i.e., "the only route along which information or influence can flow" 48 from one group to another. In other words, the weak ties in a network do something unique: they expand the radius of the connections within the network and, by doing so, they are best placed to diffuse innovation, rumor, and opinion. For this to happen, as Mark Granovetter pointed out, the presence of a "central" individual within a network is necessary in order to give the necessary authority to the information spread by the group. Using Mark Gladwell's more suggestive term, I have described such an individual as a "connector," that is, a protagonist who has the highest number of links, or ties, with the other characters of the network. As stated by Gladwell, connectors are "people with a special gift for bringing the world together" because of their ability "to occupy many different worlds and subcultures and niches" 49 and effectively navigate between them.

Indeed, the graphs shown here are particularly telling in highlighting Haywood's essential position within the poem's plot network. As seen in Figure 7, although many of her network members represent weak ties, she is overall well connected: she is directly linked to not one, but two of the three main connectors of the poem, 
Edmund Curll and John Dennis. We may hypothesize, therefore, that their elaborated campaigns against Pope involved Haywood because they acknowledged her position as an innovator (Haywood was one of the authors who established the novel on the literary marketplace), her presence in multiple cultural arenas (literary coteries, theater, press, print trade), and her involvement in moral debates that would fashion the new perceptions about women's authorship in the first half of the century. This also explains her presence in what I have called the poem's "hall of infamy" (Figure 5), i.e., dunces that are central to the Dunciad's plot network, based on their frequency rate in the poem and the apparatus. In Haywood's case, this is, again, less obvious just by reading the poem, where she is mentioned only three times (as Eliza, Juno, and "Pleas'd dame"); however, the visualizations created account for her presence in the apparatus as well, where she appears fifteen times, making evident her central role in the poem's argument.

Besides making visible the poem's main connectors, the Shiva graph is also very useful in giving the viewer a sense of the relatedness of all the characters involved in the poem. Indeed, although the characters that make The Dunciad's social network are not always directly connected, they are often involved in "a friend of a friend"-type relationship that creates tentacular ties of similarity and/or support (i.e., they all belong to the same category of "dunces" and/or support the same connector). These relationships are not always evident. Although neither Welsted nor Oldmixon was directly involved with Haywood in real life, all three are tied to Dennis: Haywood through her relationship with Aaron Hill, who was a disciple of Dennis, Oldmixon through his play, Amintas (1698), whose prologue was written by Dennis, and Welsted through.... typographical mistake that neither Dennis nor Oldmixon had noticed in their reviews of his work! ${ }^{50}$ Finally, this graph also illustrates that Pope's dunces are socially transgressive: they cross political, religious, and cultural spaces with remarkable mobility. To limit my observations to Eliza Haywood's social network, both Curll and Dennis, connectors she is linked to, supported the governing party while also acting as authors, cultural promoters, and moral counselors of the public. Thus, the Shiva graph illustrates beautifully the "multiplicity" of spaces - social, political, cultural - that describe early eighteenthcentury London, spaces which "attain 'real' existence by virtue of networks and pathways, by virtue of bunches or clusters of relationships." 51

\section{Conclusion}

So, what do these graphs do? Just as Pope did when binding together between expensive leather covers his dunces' most venomous attacks, these graphs function as instruments of information control: they provide in a condensed visual form the narrative of a case of public indictment of truly epic proportions. The maps of 
relations they unveil describe networks of communication and exchange meant to re-create (i.e., to describe in a new way), "the historical tissue" 52 of the epoch. They propose, in other words, innovative routes of investigation: they map plot and character development in a spatial configuration and represent in a diagrammatic form less obvious relationships and trajectories of events. Most importantly, they are inclusive and relational, making visible the interactions among all the characters of the poem, highlighting less visible alliances or conflicts, and providing clues to questions about social and gender roles, generic trends, and camp affiliations.

In Eliza Haywood's case, this model of social network analysis sheds new light on the motivations of Pope's attack on women writers, highlights less obvious character associations, and indicates the novelist's central position in the plot network of the poem. Figures 2 and 3 highlight the only direct connection between two women writers in the poem, Haywood and Dacier, a connection not considered significant (or considered at all) by previous scholarship. By examining the motivations of this association, it becomes evident that Pope relates the emergence of the woman writer in the first half of the eighteenth century to morally suspect hack writing and/or critical microscopia, both of which can have damaging effects on public's taste. Second, this social network analysis highlights less obvious associations between Haywood and characters she was not directly connected with outside the poem (i.e., Ward, Oldmixon, Welsted), which points to her representative value within Pope's argument, rather than being a personal target.

Also, these visualizations indicate the central role played by Haywood in the plot network of Pope's satire: although less dense when compared to other networks of the poem, her social network is directly linked to two of the three connectors of the poem, John Dennis and Edmund Curll (Figure 7), and she is part of the poem's "inner circle" of protagonists (Figure 5). Finally, as shown by the Shiva graph, the eighteenth-century public sphere was a "small world": each dunce could reach another dunce through his or her acquaintances in two to five steps, ${ }^{53}$ and a connector in only one to two steps. This finding points to the power of a decentralized routing scheme to find efficient paths to a destination through members that are not always directly connected to each other.

The conclusions that can be drawn when performing this type of analysis are even more interesting when working with larger sets of data. As seen in Figures 5 and 6, the intersections of the six social networks created during this project led to surprising results: these visualizations singled out the seventeen dunces (out of dozens) who are central to the poem's plot network, or the poem's "hall of infamy," and the four authors who are the victims of their concerted attacks, or the poem's 
"hall of fame" (i.e., Pope, Gay, Addison, and Dryden). Although this analysis can only be fully accurate when creating social networks for all, rather than only six, of Pope's dunces, the results are likely to be only refined, rather than significantly amended, by the addition of networks for characters who are less central within the poem. Most importantly, these social networks show that Pope's dunces form a cultural category that, far from representing a marginalized, minority, or disempowered group, participates, in a forceful way, in shaping public opinion. Therefore, unlike Nancy Fraser, who argues for the inclusion of "subaltern" groups in the public sphere, I contend here that Pope's dunces are engaged in discourses that place them in the same realm of public debate with cultural authorities - rather than in a subaltern position. While "counterpublic" 54 is a term that suggestively encapsulates the idea of competing interests - be they divided over class, gender, or political lines - , a networked public may better describe the collaborative nature of the public sphere of the time, which I see not as a conglomerate of divergent ideologies, but as an organic whole. 


\section{Figures}

\begin{tabular}{|c|c|c|c|c|c|c|}
\hline Character & Address & Reference & $\begin{array}{l}\text { Person } \\
\text { referred } \\
\text { to }\end{array}$ & Relationship & AKA & $\begin{array}{l}\text { Who's } \\
\text { Who }\end{array}$ \\
\hline $\begin{array}{l}\text { Haywood, } \\
\text { Eliza }\end{array}$ & $\begin{array}{l}\text { Martinus } \\
\text { Scriblerus of } \\
\text { the Poem }\end{array}$ & $\begin{array}{l}\text { Eliza, the epitome of the "libellous } \\
\text { Novellist." }\end{array}$ & & Attacked by & \multirow{5}{*}{$\begin{array}{l}\text { Eliza } \\
\text { Novelist } \\
\text { Poetess } \\
\text { Juno } \\
\text { Pholoe } \\
\text { Pleas'd } \\
\text { Dame }\end{array}$} & \multirow{5}{*}{$\begin{array}{l}\text { Novelist, } \\
\text { dramatist, } \\
\text { journalist, } \\
\text { and } \\
\text { actress }\end{array}$} \\
\hline $\begin{array}{l}\text { Haywood, } \\
\text { Eliza }\end{array}$ & $\begin{array}{l}\text { Argument to } \\
\text { Book II }\end{array}$ & The game for a Poetess & & & & \\
\hline $\begin{array}{l}\text { Haywood, } \\
\text { Eliza }\end{array}$ & II, Note to 75 & $\begin{array}{l}\text { Reference to the following episode of } \\
\text { Eliza and booksellers; similarly, in } \\
\text { MacFlecknoe, Dryden makes references } \\
\text { to excrement }\end{array}$ & & & & \\
\hline \multirow[t]{2}{*}{$\begin{array}{l}\text { Haywood, } \\
\text { Eliza }\end{array}$} & \multirow[t]{2}{*}{ II, $157-160$} & \multirow{2}{*}{$\begin{array}{l}\text { See in the circle next, Eliza plac'd, } \\
\text { Two babes of love close clinging to her } \\
\text { waist; } \\
\text { Fair as before her works she stands } \\
\text { confess'd, } \\
\text { In flow'rs and pearls by bounteous Kirkall } \\
\text { dress'd. } \\
\text { Prize in the pissing contest won by Curll; } \\
\text { associated with promiscuity. }\end{array}$} & $\begin{array}{l}\text { Richard } \\
\text { Savage }\end{array}$ & Attacked by & & \\
\hline & & & $\begin{array}{l}\text { Elisha } \\
\text { Kirkall } \\
\text { (George } \\
\text { Vertue) }\end{array}$ & Akin to & & \\
\hline
\end{tabular}




\begin{tabular}{|c|c|c|c|c|}
\hline $\begin{array}{l}\text { Haywood, } \\
\text { Eliza }\end{array}$ & $\begin{array}{l}\text { II, Note to } \\
157\end{array}$ & $\begin{array}{l}\text { "Authoress of those most scandalous } \\
\text { books called the Court of Caramania and } \\
\text { the New Utopia"; a suspect relationship } \\
\text { with Curll; reference to Haywood's } \\
\text { History of Clarina, published in the } \\
\text { Female Dunciad. }\end{array}$ & $\begin{array}{l}\text { Edmund } \\
\text { Curll }\end{array}$ & Akin to \\
\hline $\begin{array}{l}\text { Haywood, } \\
\text { Eliza }\end{array}$ & $\begin{array}{l}\text { II, Note to } \\
158\end{array}$ & $\begin{array}{l}\text { Quotation from Aeneid referring to } \\
\text { "Pholoe, of Cretan race, with twin boys at } \\
\text { the breast." }\end{array}$ & & \\
\hline $\begin{array}{l}\text { Haywood, } \\
\text { Eliza }\end{array}$ & $\begin{array}{l}\text { II, Note to } \\
160\end{array}$ & $\begin{array}{l}\text { A mention to Elisha Kirkall's portrait of } \\
\text { Eliza (actually by George Vertue) in the } \\
\text { frontispiece to Secret Histories, Novels } \\
\text { and Poem (1725), Haywood's works } \\
\text { printed in } 4 \text { volumes. }\end{array}$ & $\begin{array}{l}\text { Elisha } \\
\text { Kirkall } \\
\text { (George } \\
\text { Vertue) }\end{array}$ & Akin to \\
\hline $\begin{array}{l}\text { Haywood, } \\
\text { Eliza }\end{array}$ & II, 163-166 & $\begin{array}{l}\text { His be yon Juno of majestic size, } \\
\text { With cow-like udders, and with ox-like } \\
\text { eyes. }\end{array}$ & & \\
\hline $\begin{array}{l}\text { Haywood, } \\
\text { Eliza }\end{array}$ & $\begin{array}{l}\text { II, Note to } \\
165\end{array}$ & $\begin{array}{l}\text { Mrs. Haywood and a Jordan; the authoress } \\
\text { treated with distinction, as being the more } \\
\text { valuable of the two. }\end{array}$ & $\begin{array}{l}\text { Anne } \\
\text { Tanneguy- } \\
\text { Le Fèvre } \\
\text { Dacier }\end{array}$ & Akin to \\
\hline $\begin{array}{l}\text { Haywood, } \\
\text { Eliza }\end{array}$ & II, $187-188$ & $\begin{array}{l}\text { Thou Triumph'st, Victor of the high- } \\
\text { wrought day, } \\
\text { And the pleas'd dame, soft-smiling, } \\
\text { lead'st away... }\end{array}$ & $\begin{array}{l}\text { Edmund } \\
\text { Curll }\end{array}$ & Akin to \\
\hline $\begin{array}{l}\text { Haywood, } \\
\text { Eliza }\end{array}$ & $\begin{array}{l}\text { Appendix II } \\
\text { List of } \\
\text { abusers }\end{array}$ & $\begin{array}{l}\text { Memoirs of the Court of Lilliput. Anon. } \\
\text { [Eliza Haywood], } 1727\end{array}$ & & \\
\hline
\end{tabular}




\begin{tabular}{|l|l|l|l|l|l|}
\hline & & & & \\
\hline $\begin{array}{l}\text { Haywood, } \\
\text { Eliza }\end{array}$ & $\begin{array}{l}\text { Illustration to } \\
1729 \text { edition }\end{array}$ & $\begin{array}{l}\text { The ass carries, among others, Haywood's } \\
\text { Novels AND The Court of Caramania }\end{array}$ & $\begin{array}{l}\text { Leonard } \\
\text { Welsted }\end{array}$ & Akin to \\
\hline $\begin{array}{l}\text { Haywood, } \\
\text { Eliza }\end{array}$ & $\begin{array}{l}\text { Illustration to } \\
1729 \text { edition }\end{array}$ & & $\begin{array}{l}\text { Edward } \\
\text { Ward }\end{array}$ & Akin to \\
\hline $\begin{array}{l}\text { Haywood, } \\
\text { Eliza }\end{array}$ & $\begin{array}{l}\text { Illustration to } \\
1729 \text { edition }\end{array}$ & & $\begin{array}{l}\text { John } \\
\text { Dennis }\end{array}$ & Akin to \\
\hline $\begin{array}{l}\text { Haywood, } \\
\text { Eliza }\end{array}$ & $\begin{array}{l}\text { Illustration to } \\
1729 \text { edition }\end{array}$ & & $\begin{array}{l}\text { Lewis } \\
\text { Theobald }\end{array}$ & Akin to \\
\hline $\begin{array}{l}\text { Haywood, } \\
\text { Eliza }\end{array}$ & $\begin{array}{l}\text { Illustration to } \\
1729 \text { edition }\end{array}$ & & $\begin{array}{l}\text { John } \\
\text { Oldmixon }\end{array}$ & Akin to \\
\hline
\end{tabular}

Figure 1. Spreadsheet that captures the salient information about Eliza Haywood in the poem and apparatus: the character's address in the text, the exact reference to the character (in red when in the poem, in black when in the apparatus), the name of the person she is related to, the description of their relationship (similarity, dissimilarity, character attacked, or character defended), alternative references to Haywood, and authorial id. 


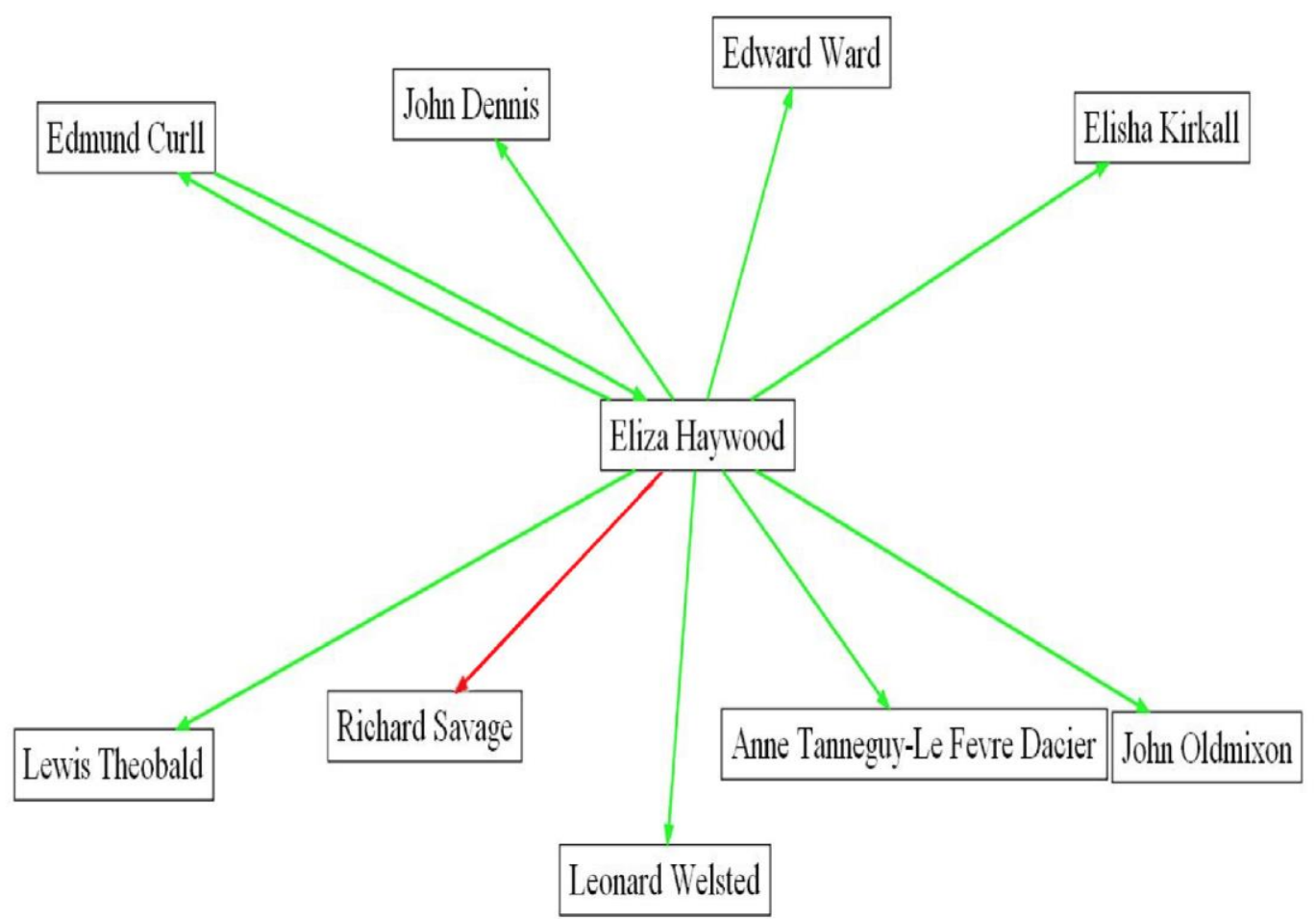

Figure 2. Graph describing Eliza Haywood's connections in the poem and the apparatus as NEATO (spring-model layout). The relations described indicate character attacked (red), and similarity (green). Haywood's relation with Curll is bidirectional, which indicates a strong tie. 


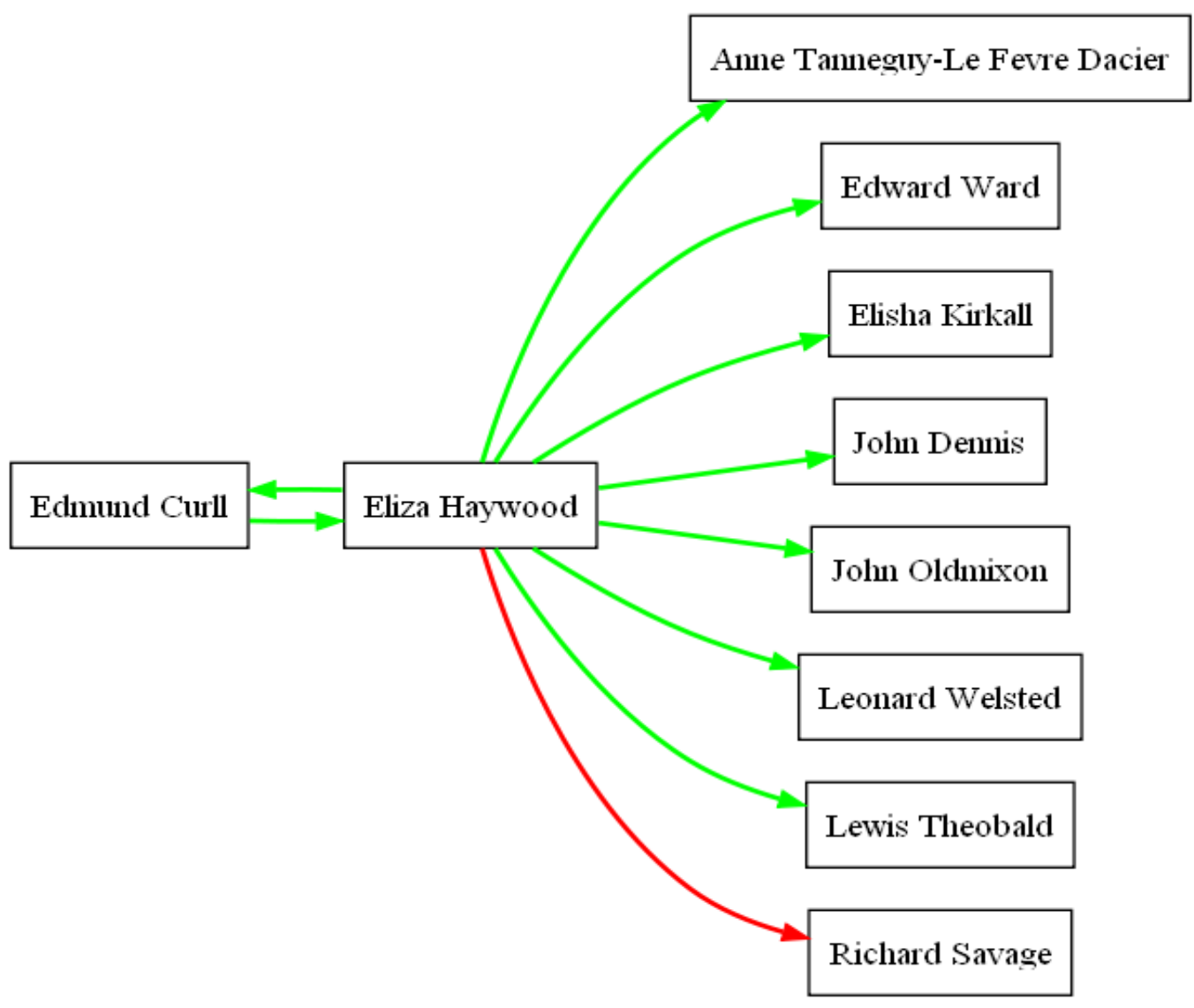

Figure 3. Graph describing Eliza Haywood's connections in the poem and the apparatus as DOT (hierarchical layout). The graph highlights Haywood's close relationship with publisher Edmund Curll, her relationship of antagonism with Savage, and her tie to Dacier, which is the only connection between two women writers in the poem. 


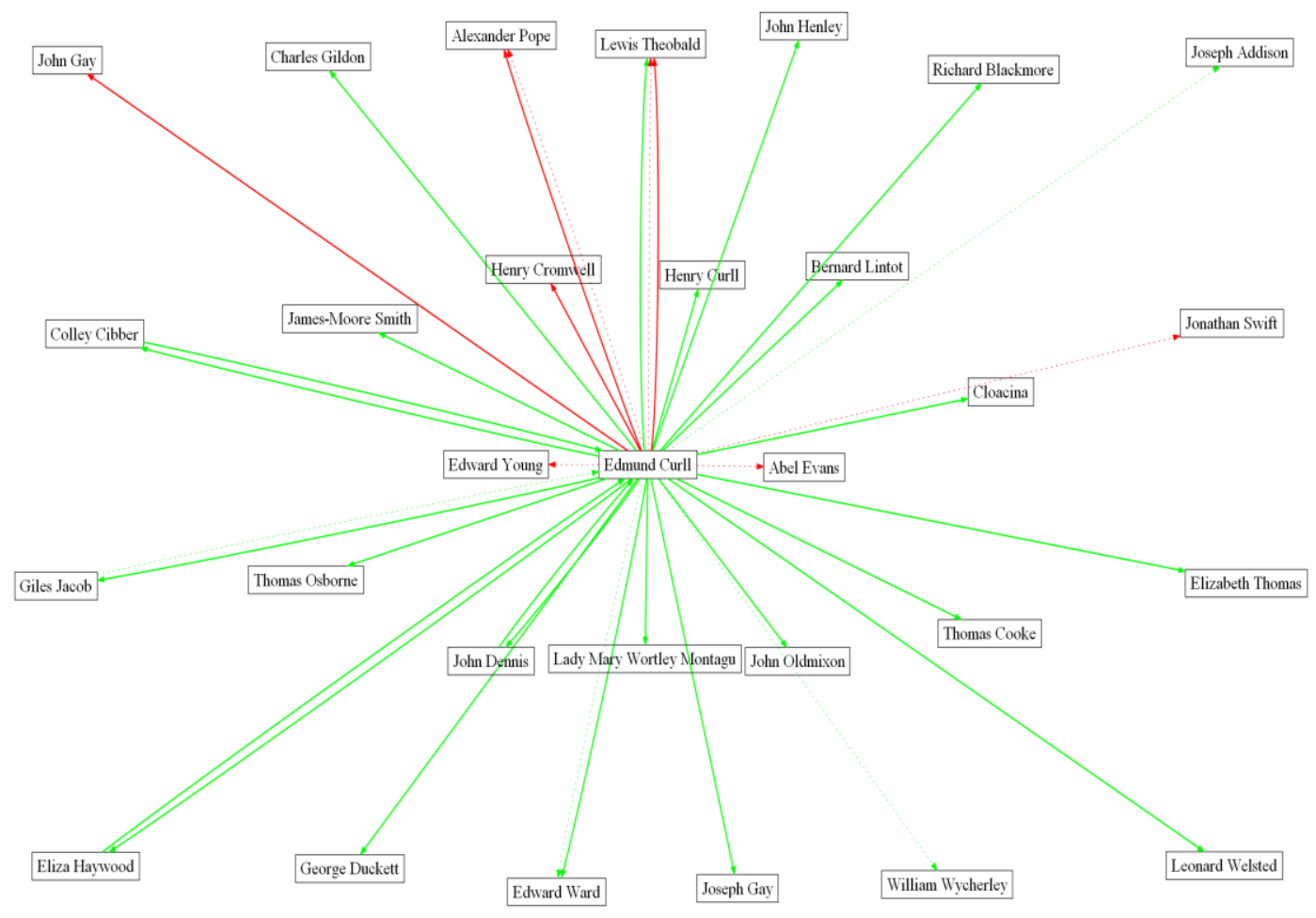

Figure 4. Graph showing all relations for Edmund Curll as NEATO (spring-model layout). The graph shows that Edward Ward, John Dennis, Leonard Welsted, Lewis Theobald, and John Oldmixon, all members of Eliza Haywood's social network, also have Curll as a common connector. 


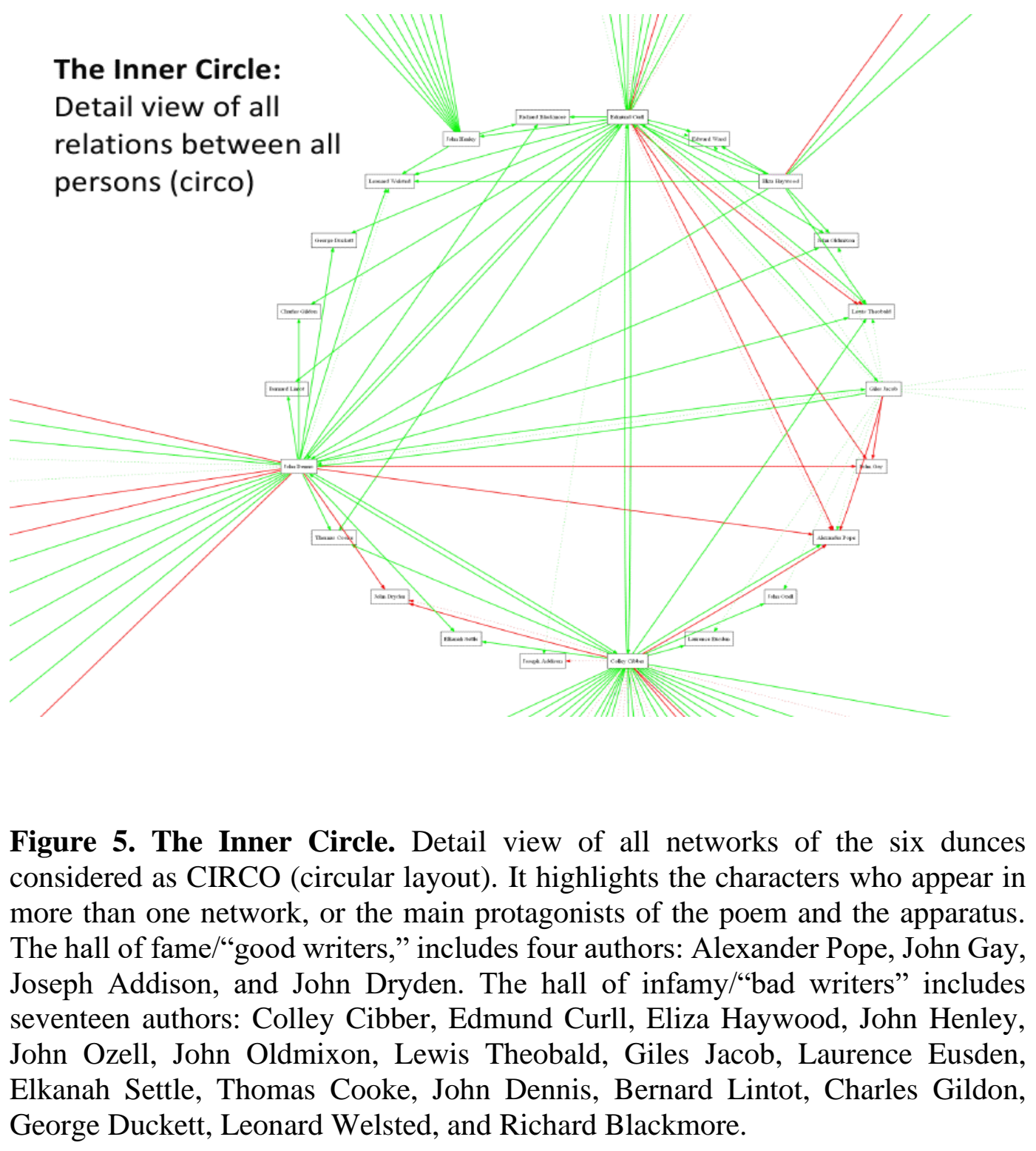


Full view of all relations between all persons (circo)

Figure 6. The Inner Circle. Full view of all networks of the six dunces considered (CIRCO). This graph highlights the central and the peripheral characters of the poem and the apparatus. 
Baird: The Strength of Weak Ties: Eliza Haywood's Social Network

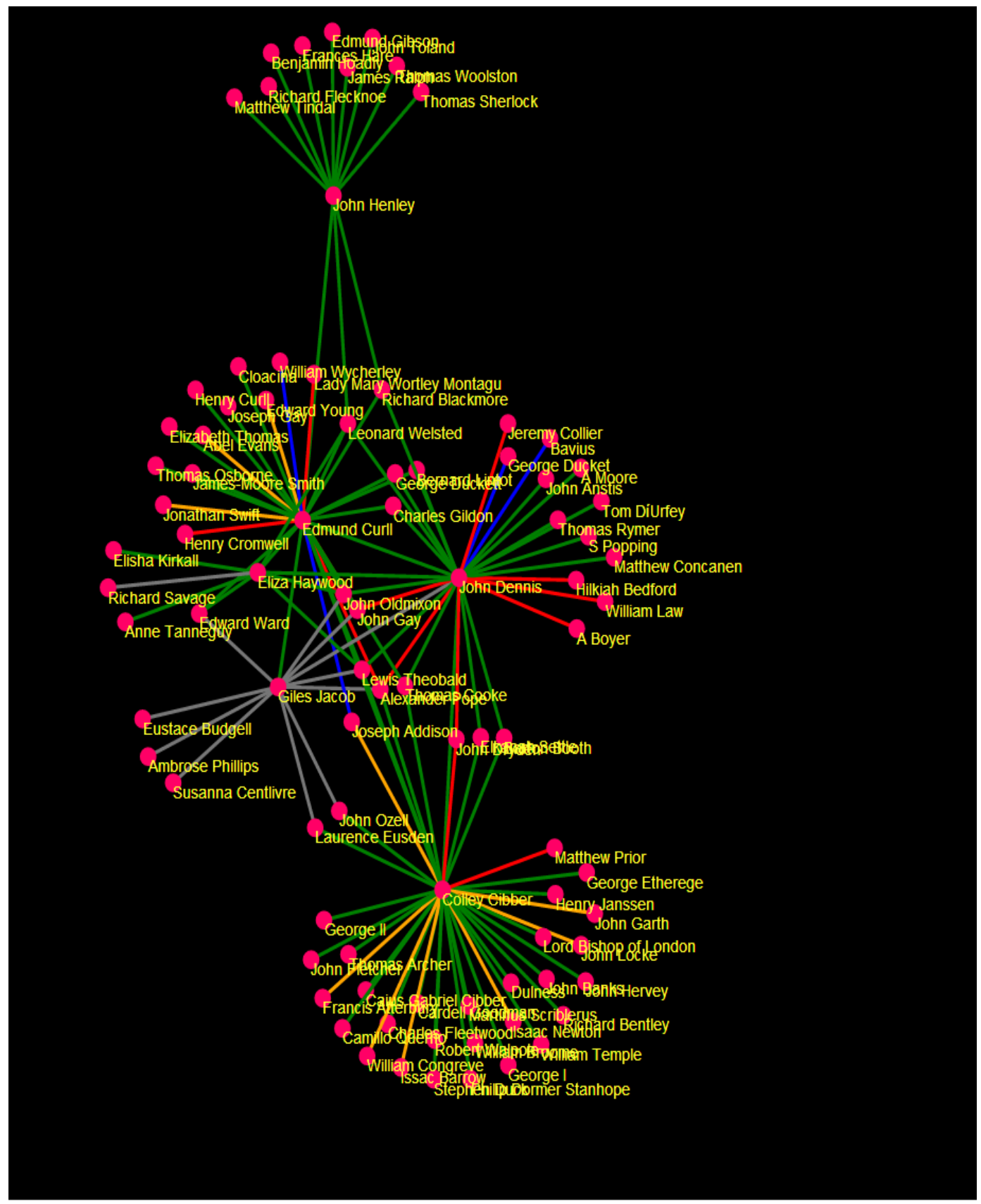

Figure 7. This Shiva graph gives the viewer a sense of the relatedness of all the characters in the poem and makes visible the poems' three "connectors" (i.e., characters with the highest number of links): Colley Cibber, Edmund Curll, and John Dennis. 


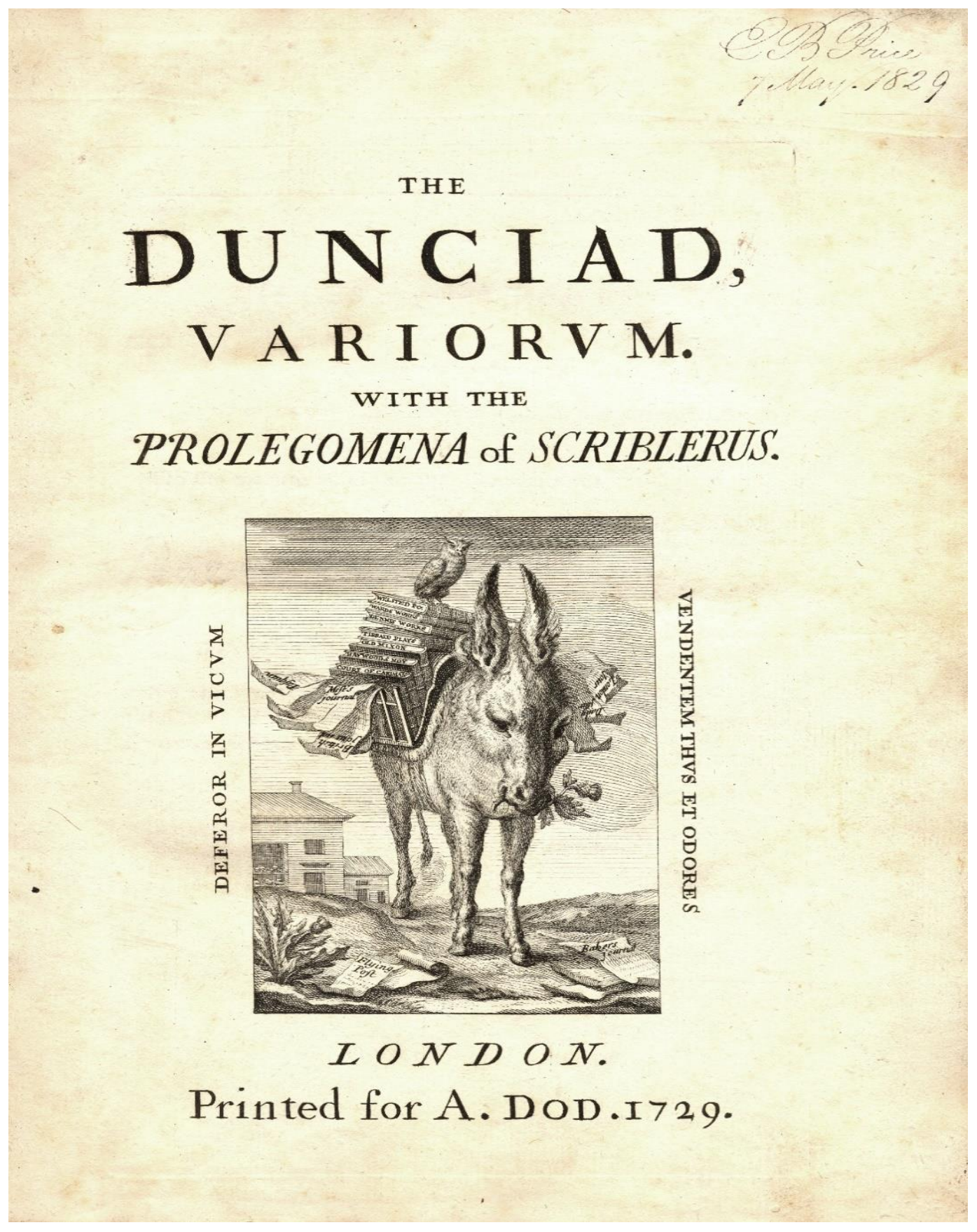

Figure 8. Title-page of The Dunciad, Variorum. With the Prolegomena of Scriblerus (1729), containing the image of the ass laden with books and journals. Courtesy of Professor David Vander Meulen, University of Virginia, Charlottesville. 


\section{NOTES}

1 "I have long observ'd that twenty miles from London no body understands hints, initial letter, or town-facts and passages; and in a few years not even those who live in London..." The Correspondence of Alexander Pope, edited by George Sherburn, vol. 2, Oxford Clarendon Press, 1956, pp. 504-505.

${ }^{2}$ Harold Weber, "The 'Garbage Heap' of Memory: At Play in Pope's Archives of Dulness," Eighteenth-Century Studies, vol. 33, no. 1, 1999, p. 15. For insightful analyses of Pope's footnotes see also Anthony Grafton, The Footnote: A Curious History, Harvard UP, 1997, p. 23, and Chuck Zerby, The Devil's Details. A History of Footnotes, Simon \& Schuster, 2002, pp. 45-58.

${ }^{3}$ I refer here to Valerie Rumbold's exemplary editions: Alexander, Pope, The Dunciad in Four Books, Pearson, 1999, and The Poems of Alexander Pope. Volume III: The Dunciad (1728) \& The Dunciad Variorum (1729), Pearson, 2007. The difficulty of this editorial enterprise deserves to be acknowledged; as David Vander Meulen has established, the poem went through three major revisions, thirty-three separate editions, and about sixty impressions by 1751 , the year of Warburton's posthumous edition of Pope's Works. Changes to the text ranged from paratextual additions (footnotes, illustrations, front and back matter) to more significant revisions, such as the replacement of the initial hero of the poem, playwright Lewis Theobald, with actor and poet laureate Colley Cibber, in The Dunciad in Four Books. I have selected the 1743 edition of the poem for my analysis as it contains Pope's final revisions of the poem and, importantly, his latest changes in characters.

${ }^{4}$ Giles Jacob was the author of The Poetical Register: or, The Lives and Characters of All the English Poets. With an Account of Their Writings (1719-1720). John Dennis accused Pope of being the "Trumpeter" of his own praise due to writing his presentation in Jacob's book. For details, see John Dennis, Remarks upon Several Passages in the Preliminaries to the Dunciad, Both of the Quarto and the Duodecimo Edition. And upon Several Passages in Pope's Preface to His Translation of Homer's Iliad. In Both Which Is Shewn the Author's Want of Judgment. With Original Letters from Sir Richard Steele, from the Late Mr. Gildon, from Mr. Jacob, and from Mr. Pope Himself, Which Shew the Falsehood of the Latter, His Envy, and His Malice, London: Printed for H. Whitridge, 1729, p. 49.

${ }^{5}$ Neato are spring-model layouts of undirected graphs (i.e., graphs in which all nodes are connected and the edges are bidirectional); this is the default tool to use if the graph is not too large (about 100 nodes) and when trying to identify high or low energy configurations (in our case, main agents/connectors vs. peripheral characters). Circo are circular layouts of undirected graphs; they are very useful in highlighting relationships between agents/objects or positions within a network (in our case, the main targets of Pope's attacks - or the poem's "hall of infamy"-, and the main targets of his dunces' attacks — or the poem's "hall of fame"). Dot graphs are hierarchical, or layered drawings of directed graphs (i.e., graphs in which all the edges are directed from one node to another); this is the default tool to use if edges have directionality, such as in dependency trees (in our case, they show Haywood's involvement in relationships with characters who are not connected with each other in her own social network).

${ }^{6}$ Alex Woloch, The One vs. the Many: Minor Characters and the Space of the Protagonist in the Novel, Princeton UP, 2003.

${ }^{7}$ Franco Moretti, Graphs, Maps, Trees: Abstract Models for a Literary History, Verso, 2005, p. 54. ${ }^{8}$ The nickname was launched by Henry Fielding in The Author's Farce where Haywood is described as a "Romance Writer" (58) who lives in the style of her erotic fictions, having an amorous affair with Signior Opera. For details, see The Author's Farce; and The Pleasures of the Town. As Acted in the Theatre in the Hay-Market. Written by Scriblerus Secundus, London: Printed for J. Roberts, 1730 . 
${ }_{9}^{9}$ Thomas Osborne replaced in The Greater Dunciad (1743) Samuel Chapman and William Rufus Chetwood, both booksellers who had published works by Eliza Haywood and had promoted her work. The pissing pot episode was inspired by a real event involving Chetwood who, "in a drunken Debauch ... was sent Home with a Jordan, alias, a P-ss-Pot on his Head" (13). For details, see $A$ Compleat Key to the Dunciad, London: Printed for E. Curll, 1728. As for Osborne, he was included in the last revision of The Dunciad for reasons that had nothing to do with Haywood: he most likely had inflamed Pope when he cut down the folio copies of his translation of the Iliad to pass them off as quartos. For details, see O. M. Brack, "Osborne, Thomas," Oxford Dictionary of National Biography, https://doi.org/10.1093/ref:odnb/20885.

${ }^{10}$ Pope's anger against Haywood was, indeed, formidable: in the earlier editions of The Dunciad (1728; 1729), the lines about Haywood were even harsher, containing a now cancelled passage that placed her in the same moral and literary category with Curll's "Corinna" (II, 1. 66), i.e., Elizabeth Thomas. Thomas (1675-1731) was a poetess previously praised by Dryden; her conflict with Pope arose from her selling to Curll letters that Pope had sent to his friend, Henry Cromwell. In both her and Haywood's case, Pope implied that the authoresses had intimate relationships with the publisher.

${ }^{11}$ In The Dunciad, Pope also refers to "novels, plays and obscene books" (I, note to 1. 147) in a suggestive list that draws attention to their shared profanity. In his dedication to The Rape of the Lock, Pope describes novels as containing "fabulous passages, fictitious human persons, [and] gentle Spirits," alludes to their extravagant titles and voluminous size, and identifies "the Fair Sex" as their main readership (The Works of Alexander Pope, Esq. In Nine Volumes Complete. With His Last Corrections, Additions, and Improvements. Published by Mr. Warburton, vol. 1, London: Printed for J. and P. Knapton, H. Lintot, J. and R. Tonson, and S. Draper, 1751, pp. 129-30). Finally, in the "Preface to the Works of Shakespear," Pope compares the plots of modern comedies to those "of any novel" and he contrasts them to "true history" (The Works of Alexander Pope, vol. 6, p. $333)$.

${ }^{12}$ See, for instance, George Sherburn, The Early Career of Alexander Pope, Clarendon Press, 1934, p. 296; James Sutherland, ed. The Dunciad, Volume 5: The Twickenham Edition of the Poems of Alexander Pope, 2nd ed., London: Methuen, 1953, p. 119; and Rumbold, ed., The Dunciad in Four Books, p. 171.

${ }^{13}$ Eliza Fowler Haywood, Memoirs of a Certain Island Adjacent to the Kingdom of Utopia. Written by a Celebrated Author of That Country. Now Translated into English, 2nd ed., vol. 1, London: Printed and Sold by the Booksellers of London and Westminster, 1726, p. 12.

${ }^{14}$ For details, see Kathryn R. King, A Political Biography of Eliza Haywood, Routledge, 2012, pp. 42-43.

${ }^{15}$ For two different views on the reasons for Haywood's attack, see Kathryn R. King, "Eliza Haywood, Savage Love, and Biographical Uncertainty," The Review of English Studies, vol. 59, no. 242, 2008, pp. 722-39, and Christine Gerrard, "The Hillarian Circle: Scorpions, Sexual Politics and Heterosocial Coteries," in Re-Evaluating the Literary Coterie, 1580-1830: From Sidney to Blackwood's, edited by Will Bowers and Hannah Leah Crummé, Palgrave, 2016, pp. 93-110.

${ }^{16}$ Interestingly, Richard Savage and Eliza Haywood had not always been at odds. They seem to have met when she arrived in London in 1717, moved through the same theatrical and book trade circles, had an affair sometime in 1719, and some even suggest that Savage fathered one of her children. During that time, Savage wrote verses in praise of two of Haywood's early novels, Love in Excess (1719) and The Rash Resolve (1724), and was on friendly terms with Chetwood, her first publisher. It is not clear what triggered their estrangement, but while Haywood tried to make amends in some of her writings, Savage attacked her openly in The Authors of the Town (1725) and An Author to be Lett (1729) and provided Pope with fuel for his satire.

${ }^{17}$ As Kathryn R. King elucidated, some of those attacked in Caramania include the earl of Scarborough (Marmillio), duke of Argyll (Ariadno), and maid of honor May Belleden (Lutetia). For 
details, see King, "Of Grub Street and Grudges: Haywood's Court of Caramania and Pope's Ire," The Review of English Studies, vol. 67, no. 281, 2016, p. 727.

${ }^{18}$ The Works of Jonathan Swift, edited by Walter Scott, 2nd ed., vol. 17, London: Bickers \& Son, 1883 , p. 430.

${ }^{19}$ An interesting explanation of the purpose of this piece is offered by Catherine Ingrassia, who points to Haywood's indirect criticism of Pope's attack on her: "Like Clarina, Haywood has had her reputation destroyed by a faithless man, and her text highlights Pope's (new) reputation for viciously representing women" (70). See Authorship, Commerce, and Gender in Early Eighteenth-Century England. A Culture of Paper Credit, Cambridge UP, 1998.

${ }^{20}$ Aaron Hill (1685-1750) was a writer, literary patron, and founder of the Hillarian circle, which included authors such as Edward Young, Richard Savage, John Dyer, David Mallet, James Thomson, Eliza Haywood, and Martha Sansom (formerly Fowke). Pope attacks him first in Peri Bathous (1727), where he describes Hill as a "flying fish," and then in The Dunciads, where he describes Hill as a mud-diving writer (both allusions to Hill's inability to sustain the sublime style). Hill answers back in The Progress of Wit (1730), where he forecasts Pope's disappearance down the vortex of oblivion due to his insistence to write on low subject matters.

${ }^{21}$ William Bond (d. 1735) was a journalist, dramatist, and translator who published a satire on John Gay, Pope's friend, under the fictitious signature "H. Stanhope." Bond attacked Pope in The Progress of Dulness (1728), where he disparaged Windsor Forest and complimented Spenser at the expense of Pope for his allegory on the battle of the sexes, also employed by Pope in The Rape of the Lock (1712; 1714/15). Bond co-edited with Hill The Plain Dealer (1724-1725).

${ }^{22}$ Appendix II was compiled in 1729 as a justification for Pope's retaliation against dunces who had abused him in their works; this list was slightly updated in the 1743 edition.

${ }^{23}$ This attribution has been contested by several critics and the Memoirs of the Court of Lilliput is no longer considered as one of Haywood's works. For details, see Patrick Spedding, A Bibliography of Eliza Haywood, Pickering \& Chatto, 2004, p. 647.

${ }^{24}$ Memoirs of the Court of Lilliput. Written by Captain Gulliver. Containing an Account of the Intrigues, and Some Other Particular Transactions of That Nation, Omitted in the Two Volumes of His Travels, Published by Lucas Bennet, with a Preface, Shewing How These Papers Fell into His Hands, London: Published for J. Roberts, 1727, pp. 16-17.

${ }^{25}$ According to George Frisbee Whicher, between 1731 and 1741, Eliza Haywood produced fewer books than during any single year of her activity after the publication of Idalia and before The Dunciad, and most of these titles were published anonymously. See Whicher, The Life and Romances of Mrs. Eliza Haywood, Columbia UP, 1915.

${ }^{26}$ According to Christine Blouch, "Haywood was not only not silenced by Pope, but capitalized on her post-Dunciad notoriety during the early years of the decade" (541): she acted in six plays, authored at least three, and published The Dramatic Historiographer, a theater compendium that ran seven one- and two-volume editions between 1735 and 1756, establishing her reputation as "an arbiter of the London theater scene of the period" (543). For details, see Christine Blouch, "Eliza Haywood and the Romance of Obscurity," Studies in English Literature, 1500-1900, vol. 31, no. 3, Restoration and Eighteenth Century, 1991, pp. 535-52, and Blouch's biographical introduction, "Eliza Haywood," in The Selected Works of Eliza Haywood I, Volume 1: Miscellaneous Writings, 1725-1743, edited by Alexander Pettit, Pickering \& Chatto, 2000, pp. xlvi-xlviii.

${ }^{27}$ Haywood's publication of the Female Spectator (1744-1746), arguably the first periodical written by a woman for women, was the culmination point of a lifelong career as a political propagandist, literary critic, and social commentator started in the 1720s with The Tea Table (1724). These publications played an essential role in creating a feminist niche in the literary public sphere.

${ }^{28}$ Anthony Pollock, "Voyeurism, Feminist Impartiality, and Cultural Authority. Haywood and the Addisonian Periodical," in Gender and the Fictions of the Public Sphere, 1690-1755, Routledge, 2009, p. 165. 
${ }^{29}$ Eliza Haywood, Frederick, Duke of Brunswick-Lunenburgh. A Tragedy, London: Printed for W. Mears and J. Brindley, 1729, n.p. Interestingly, Haywood's assessment of Pope in her own writings is overwhelmingly positive, usually quoting memorable verses by the poet and mentioning his good judgment. The only negative assessment of Pope I could find in her work is literary, not personal: "Mr. Pope, whose poetical works will always be read with an equal share of pleasure and admiration, had, notwithstanding, no genius to dramatic writing." See Eliza Haywood, The Female Spectator, 3rd ed., vol. 2, London: Printed and published by T. Gardner, 1750, p. 72.

${ }^{30}$ See King, Pollock, and Blouch, to name just a few.

${ }^{31}$ Valerie Rumbold, "Cut the Caterwauling: Women Writers (Not) in Pope's Dunciads," The Review of English Studies, vol. 52, no. 208, 2001, pp. 524-25.

${ }^{32}$ Rumbold, "Cut the Caterwauling," p. 529.

${ }^{33}$ Rumbold, "Cut the Caterwauling," p. 528.

34 "Madam Dacier's Reflections upon Mr. Pope's Account of Homer, in his Preface to the Iliad," in The Popiad, London: 1728, p. 26.

35 "Madam Dacier's Reflections," p. 31.

36 "Madam Dacier's Reflections," p. 31-32.

37 "Conclusion," The Popiad, p. 32.

${ }^{38}$ Qtd. in Howard D. Weinbrot, "Alexander Pope and Madame Dacier's Homer: Conjectures concerning Cardinal Dubois, Sir Luke Schaub, and Samuel Buckley," Huntington Library Quarterly, vol. 62, no. 1/2, 1999, p. 2.

${ }^{39}$ This analysis suggests that the inclusion of Margaret Cavendish, and the intention to include Mary Prix and Lady Frances Norton in the poem, all authors who did not personally clash with Pope or his friends, was not an anomaly: all these authors are criticized either for their lack or reason (Dacier, Norton) or literary over-productivity (Haywood, Cavendish, Prix).

${ }^{40}$ Haywood and Curll were continuously paired in other anti-Haywood attacks as well. In Richard Savages' An Author to Be Lett (1729), for instance, Haywood was described as belonging to the same "Club of Dunces" that included James Moore-Smythe, Lewis Theobald, Leonard Welsted, John Dennis, Thomas Cooke, Bezaleel Morrice, and Edmund Curll.

${ }^{41}$ The following are only some of the books authored by "dunces" and sold or published by Curll between 1712 and 1742, according to his catalogues of books and pamphlets: John Dennis, Letters, Moral and Critical (1721), and The Popiad (1728); John Oldmixon, The Secret History of Europe. Part III (1715; 1733), Life of Arthur Maynwaring, Esq. (1715), Critical History of England (1722), Court Tales: or a History of the Amours of the Present Nobility, with a Compleat Key (1735), and History of the Reformation (1739); Lewis Theobald, Collection of Original Poems (1721), Miscellaneous Poems (1721), and a collective translation of Ovid's Metamorphoses (1721); Ned Ward, The Life and Notable Adventures of That Renown'd Knight Don Quixote de la Mancha, Merrily Translated in Hudibrastic Verse (1712). For more details, see the "Index of Curll's Publications," in Paul Baines and Pat Rogers, Edmund Curll, Bookseller, 2nd ed., Oxford UP, 2013, pp. 371-77.

${ }^{42}$ David L. Vander Meulen, Pope's Dunciad of 1728. A History and Facsimile, U of Virginia P, 1991, pp. 36-37.

${ }^{43}$ For a detailed discussion of all the character attributions associated with this image, see Ileana Baird, "Visual Paratexts: The Dunciad Illustrations and the Thistles of Satire," in Book Illustration in the Long Eighteenth Century: Reconfiguring the Visual Periphery of the Text, edited by Christina Ionescu, Cambridge Scholars Publishing, pp. 333-39.

${ }^{44}$ Lewis Theobald, Shakespeare Restored: or a Specimen of the Many Errors as Well Committed, as Unamended, by Mr. Pope in His Late Edition of This Poet, London: Printed for R. Francklin et. al., 1726 .

${ }^{45}$ John Oldmixon, Reflections on Dr. Swift's Letter to the Earl of Oxford about the English Tongue, London, 1712. 
46 Pat Rogers. "Oldmixon, John," Oxford Dictionary of National Biography, https://doi.org/10.1093/ref:odnb/20695. Accessed 6 August 2018.

${ }^{47}$ In "The Strength of Weak Ties," Mark S. Granovetter demonstrates the importance of connections with people who are not members of one's close group of friends for innovation diffusion and coalition building (The American Journal of Sociology, vol. 78, no. 6, 1973, pp. 1360-80).

${ }^{48}$ Granovetter 1364.

${ }^{49}$ The Tipping Point. How Little Things Can Make a Big Difference, Back Bay Books, 2000, pp. 38 and 48 , respectively.

${ }^{50}$ In Book III of The Dunciad, Pope comments on Welsted's qualities as a literary critic, signaling a gross typographic mistake unobserved by him ("By his broad shoulders known, and length of ears," instead of "years"), as well as by some other "accurate persons," such as Dennis and Oldmixon (note to 1. 36).

${ }^{51}$ Henry Lefebvre, The Production of Space, translated by Donald Nicholson-Smith, Blackwell Publishers, 1995, p. 86.

${ }^{52}$ Moretti 98.

${ }^{53}$ Stanley Milgram, "The Small World Problem," Psychology Today, vol. 1, no. 1, 1967, p. 65.

${ }^{54}$ Nancy Fraser, "Rethinking the Public Sphere: A Contribution to the Critique of Actually Existing Democracy," Social Text, no. 25/26, 1990, p. 61. 


\section{Works Cited}

Baird, Ileana. "Visual Paratexts: The Dunciad Illustrations and the Thistles of Satire." Book Illustration in the Long Eighteenth Century: Reconfiguring the Visual Periphery of the Text, edited by Christina Ionescu, Cambridge Scholars Publishing, pp. 329-66.

Baines, Paul and Pat Rogers. Edmund Curll, Bookseller. 2nd ed., Oxford UP, 2013.

Blouch, Christine. "Eliza Haywood.” The Selected Works of Eliza Haywood, Set I, Volume 1, Miscellaneous Writings, 1725-1743, edited by Alexander Pettit, Pickering \& Chatto, 2000.

---. "Eliza Haywood and the Romance of Obscurity," Studies in English Literature, 1500-1900, vol. 31, no. 3, Restoration and Eighteenth Century, 1991, pp. 535-52.

Brack, O. M. "Osborne, Thomas," Oxford Dictionary of National Biography, https://doi.org/10.1093/ref:odnb/20885.

Curll, Edmund. A Compleat Key to the Dunciad. London: Printed for A. Dodd, 1728.

Dennis, John. Remarks upon Several Passages in the Preliminaries to the Dunciad, Both of the Quarto and the Duodecimo Edition. And upon Several Passages in Pope's Preface to His Translation of Homer's Iliad. In Both Which Is Shewn the Author's Want of Judgment. With Original Letters from Sir Richard Steele, from the Late Mr. Gildon, from Mr. Jacob, and from Mr. Pope Himself, Which Shew the Falsehood of the Latter, His Envy, and His Malice. London: Printed for H. Whitridge, 1729.

Fielding, Henry. The Author's Farce; and The Pleasures of the Town. As Acted in the Theatre in the Hay-Market. Written by Scriblerus Secundus. London: Printed for J. Roberts, 1730.

Fraser, Nancy. "Rethinking the Public Sphere: A Contribution to the Critique of Actually Existing Democracy." Social Text, no. 25/26, 1990, pp. 56-80.

Gerrard, Christine. "The Hillarian Circle: Scorpions, Sexual Politics and Heterosocial Coteries." Re-evaluating the Literary Coterie, 1580-1830: 
From Sidney to Blackwood's, edited by Will Bowers and Hannah Leah Crummé, Palgrave, 2016, pp. 93-109.

Gladwell, Malcolm. The Tipping Point. How Little Things Can Make a Big Difference. Back Bay Books, 2000.

Grafton, Anthony. The Footnote: A Curious History. Harvard UP, 1997.

Granovetter, Mark S. "The Strength of Weak Ties." The American Journal of Sociology, vol. 78, no. 6, 1973, pp. 1360-80.

Haywood, Eliza. Frederick, Duke of Brunswick-Lunnenburgh. A Tragedy. London: Printed for W. Mears and J. Brindley, 1729.

---. Irish Artifice or, The History of Clarina. London: Printed for T. Read, 1728.

---. Memoirs of a Certain Island Adjacent to the Kingdom of Utopia. Written by a Celebrated Author of That Country. Now Translated into English. Vol. 1, London: Printed and sold by the Booksellers of London and Westminster, 1725 .

---. Secret Histories, Novels and Poems: In Four Volumes. Written by Mrs. Eliza Haywood. London: Printed [partly by Samuel Aris] for Dan. Browne, jun. and S. Chapman, 1725.

---. The Female Spectator. 3rd ed., vol. 2. London: Printed and published by T. Gardner, 1750.

---. The Secret History of the Present Intrigues of the Court of Caramania. London: Printed and sold by the Booksellers of London and Westminster, 1727.

Ingrassia, Catherine. Authorship, Commerce, and Gender in Early EighteenthCentury England. A Culture of Paper Credit. Cambridge UP, 1998.

Jacob, Giles. The Poetical Register: or, The Lives and Characters of All the English Poets. With an Account of Their Writings. London: Printed for E. Curll, 1719-1720. 2 vols.

King, Kathryn R. A Political Biography of Eliza Haywood. Routledge, 2012. 
---. "Eliza Haywood, Savage Love, and Biographical Uncertainty." The Review of English Studies, vol. 59, no. 242, 2018, pp. 722-39.

---. "Of Grub Street and Grudges: Haywood's Court of Caramania and Pope's Ire." The Review of English Studies, vol. 67, no. 281, 2016, pp. 713-31.

Lefebvre, Henry. The Production of Space. Translated by Donald Nicholson-Smith. Blackwell Publishers, 1995.

"Madam Dacier's Reflections upon Mr. Pope's Account of Homer, in His Preface to the Iliad." The Popiad. London: 1728, pp. 26-32.

Memoirs of the Court of Lilliput. Written by Captain Gulliver. Containing an Account of the Intrigues, and Some Other Particular Transactions of That Nation, Omitted in the Two Volumes of His Travels, Published by Lucas Bennet, with a Preface, Shewing How These Papers Fell into His Hands. London: Published for J. Roberts, 1727.

Milgram, Stanley. "The Small World Problem." Psychology Today, vol. 1, no. 1, 1967, pp. 61-67.

Moretti, Franco. Graphs, Maps, Trees: Abstract Models for a Literary History. Verso, 2005.

Oldmixon, John. Reflections on Dr. Swift's Letter to the Earl of Oxford about the English Tongue. London: Sold by A. Baldwin, 1712.

Pollock, Anthony. Gender and the Fictions of the Public Sphere, 1690-1755. Routledge, 2009.

Pope, Alexander. The Dunciad in Four Books. Edited by Valerie Rumbold, Pearson, 1999.

Portes, Alexandro, "Social Capital: Its Origins and Applications in Modern Sociology." Annual Review of Sociology, vol. 24, 1998, pp. 1-24.

Reeve, Clara. The Progress of Romance, through Times, Countries, and Manners: With Remarks on the Good and Bad Effects of It, on Them Respectively: In a Course of Evening Conversations. London: Printed for the Author by W. Keymer, 1785. 
Rogers, Pat. "Oldmixon, John," Oxford Dictionary of National Biography, https://doi.org/10.1093/ref:odnb/20695.

Rumbold, Valerie, "Cut the Caterwauling: Women Writers (Not) in Pope's Dunciads." The Review of English Studies, vol. 52, no. 208, 2001, pp. 52439.

Savage, Richard. An Author to Be Lett. Being a Proposal Humbly Address'd to the Consideration of the Knights, Esquires, Gentlemen, and Other Worshipful and Weighty Members of the Solid and Ancient Society of the Bathos by Their Associate and Well-Wisher Iscariot Hackney. London: Printed for Alexander Vint, 1729.

---. The Authors of the Town; A Satire: Inscribed to the Author of the Universal Passion. London: Printed for J. Roberts, 1725.

Sherburn, George. The Early Career of Alexander Pope. Clarendon Press, 1934.

Spedding, Patrick. A Bibliography of Eliza Haywood. Pickering \& Chatto, 2004.

The Author's Farce; and The Pleasures of the Town. As Acted in the Theatre in the Hay-Market. Written by Scriblerus Secundus. London: Printed for J. Roberts, 1730.

The Correspondence of Alexander Pope. Edited by George Sherburn, vol. 2, Oxford, 1956.

The Dunciad. Volume 5: The Twickenham Edition of the Poems of Alexander Pope. Edited by James Sutherland, 2nd ed., London: Methuen, 1953.

The Female Dunciad: Containing I. A Faithful Account of the Intrigues, Gallantries and Amours of Alexander Pope, of Twickenham, Esq. Written by Himself. II. A Satire upon the Court-Lords and Ladies. Written also by Him in the Year 1717. III. A Single Instance of His Repentance. IV. The New, Surprising Metamorphosis: or, Mr. Pope Turn'd into a Stinging Nettle; Being a Familiar Epistle from a Gentleman in Town to a Lady in the Country. Occasion'd by Reading the Dunciad. V. Irish Artifice; or, The History of Clarina. A Novel. By Mrs. Eliza Haywood. VI. Female Worthies. By the Bishop of Peterborough. The Whole Being a Continuation of the Twickenham Hotch-Potch. London: Printed for T. Read, 1728. 
The Poems of Alexander Pope. Volume III: The Dunciad (1728) \& The Dunciad Variorum (1729). Edited by Valerie Rumbold, 2nd ed., Routledge, 2013.

The Works of Alexander Pope, Esq. In Nine Volumes Complete. With His Last Corrections, Additions, and Improvements. Published by Mr. Warburton. London: Printed for J. and P. Knapton, H. Lintot, J. and R. Tonson, and S. Draper, 1751.9 vols.

The Works of Jonathan Swift. Edited by Sir Walter Scott, 2nd ed., vol. 17. London: Bickers \& Son, 1883.

Theobald, Lewis. Shakespeare Restored: or a Specimen of the Many Errors as Well Committed, as Unamended, by Mr. Pope in His Late Edition of This Poet. London: Printed for R. Francklin et. al., 1726.

Vander Meulen, David. Pope's Dunciad of 1728. A History and Facsimile. The University of Virginia Press, 1991.

Weinbrot, Howard D. “Alexander Pope and Madame Dacier's Homer: Conjectures concerning Cardinal Dubois, Sir Luke Schaub, and Samuel Buckley." Huntington Library Quarterly, vol. 62, no. 1/2, 1999, pp. 1-23.

Welsted, Leonard. "Pælemon to Cæliat at Bath; or The Triumvirate." The Works, in Verse and Prose, or Leonard Welsted, Esq. Some Time Clerk in Ordinary at the Office of Ordnance in the Tower of London. Now First Collected. With Historical Notes and Biographical Memoirs of the Author, by John Nichols. London: Printed by and for the Editor, 1787.

Whicher, George Frisbie. The Life and Romances of Mrs. Eliza Haywood, Columbia UP, 1915.

Woloch, Alex. The One vs. the Many: Minor Characters and the Space of the Protagonist in the Novel. Princeton UP, 2003.

Zerby, Chuck. The Devil's Details. A History of Footnotes. Simon \& Schuster, 2002. 